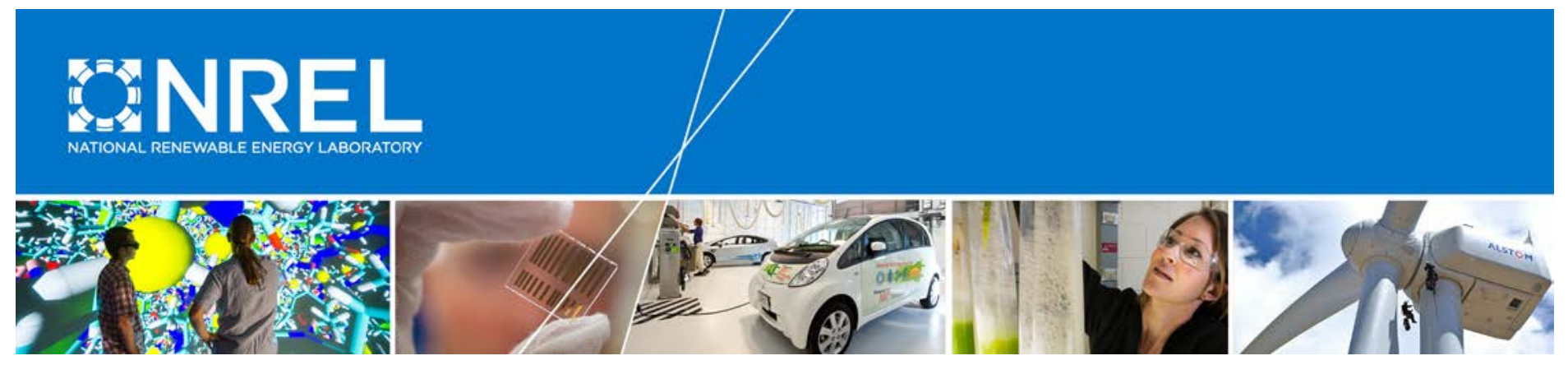

\title{
Water Constraints in an Electric Sector Capacity Expansion Model
}

Jordan Macknick, Stuart Cohen, Robin Newmark, Andrew Martinez, and Patrick Sullivan National Renewable Energy Laboratory

Vince Tidwell

Sandia National Laboratories

NREL is a national laboratory of the U.S. Department of Energy Office of Energy Efficiency \& Renewable Energy Operated by the Alliance for Sustainable Energy, LLC

This report is available at no cost from the National Renewable Energy Laboratory (NREL) at www.nrel.gov/publications.

Technical Report

NREL/TP-6A20-64270

July 2015

Contract No. DE-AC36-08GO28308 


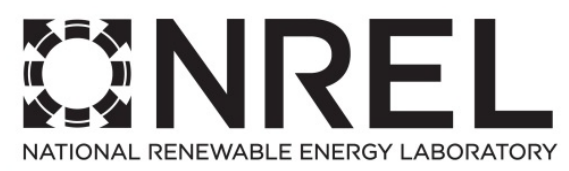

\section{Water Constraints in an Electric Sector Capacity Expansion Model}

Jordan Macknick, Stuart Cohen, Robin Newmark, Andrew Martinez, and Patrick Sullivan National Renewable Energy Laboratory

Vince Tidwell

Sandia National Laboratories

Prepared under Task No. 066A.1501

NREL is a national laboratory of the U.S. Department of Energy Office of Energy Efficiency \& Renewable Energy Operated by the Alliance for Sustainable Energy, LLC

This report is available at no cost from the National Renewable Energy Laboratory (NREL) at www.nrel.gov/publications.

National Renewable Energy Laboratory 15013 Denver West Parkway Golden, CO 80401 303-275-3000 • www.nrel.gov

\section{Technical Report}

NREL/TP-6A20-64270

July 2015

Contract No. DE-AC36-08G028308 


\title{
NOTICE
}

This report was prepared as an account of work sponsored by an agency of the United States government. Neither the United States government nor any agency thereof, nor any of their employees, makes any warranty, express or implied, or assumes any legal liability or responsibility for the accuracy, completeness, or usefulness of any information, apparatus, product, or process disclosed, or represents that its use would not infringe privately owned rights. Reference herein to any specific commercial product, process, or service by trade name, trademark, manufacturer, or otherwise does not necessarily constitute or imply its endorsement, recommendation, or favoring by the United States government or any agency thereof. The views and opinions of authors expressed herein do not necessarily state or reflect those of the United States government or any agency thereof.

This report is available at no cost from the National Renewable Energy Laboratory (NREL) at www.nrel.gov/publications.

Available electronically at SciTech Connect http:/www.osti.gov/scitech

Available for a processing fee to U.S. Department of Energy and its contractors, in paper, from:

\author{
U.S. Department of Energy \\ Office of Scientific and Technical Information \\ P.O. Box 62 \\ Oak Ridge, TN 37831-0062 \\ OSTI http://www.osti.gov \\ Phone: 865.576.8401 \\ Fax: 865.576.5728 \\ Email: reports@osti.gov
}

Available for sale to the public, in paper, from:

\author{
U.S. Department of Commerce \\ National Technical Information Service \\ 5301 Shawnee Road \\ Alexandria, VA 22312 \\ NTIS http://www.ntis.gov \\ Phone: 800.553 .6847 or 703.605 .6000 \\ Fax: 703.605.6900 \\ Email: orders@ntis.gov
}




\section{Acknowledgments}

This work was funded through a Laboratory Directed Research and Development (LDRD) grant from the National Renewable Energy Laboratory (NREL). The authors would like to thank the following individuals for their thoughtful comments, input, and review of the document in its various stages: James Meldrum (University of Colorado); Stacy Tellinghuisen (Western Resource Advocates); and Laura Vimmerstedt, Maggie Mann, Tibebe Woldeyesus, Jesse Colman, Dave Mooney, and Daniel Steinberg (NREL). The authors also appreciate the graphical contributions of Billy Roberts (NREL) and the editorial support of Kendra Palmer (NREL). 


\section{Introduction}

The thermoelectric sector is the largest withdrawer of freshwater in the nation (Kenny et al. 2009). The dominant use of water in power plants is for cooling. As a result of elevated water temperatures or lack of available water, power plants in various regions throughout the United States have had to curtail generation or shut down (Department of Energy 2013). Concerns over water availability in the past have affected decisions on where power plants could be built and what types of cooling systems they could employ (Averyt et al. 2011; Rogers et al. 2013). Water usage refers to two metrics: "withdrawal," which is water removed from the ground or diverted from a source for use, and "consumption," which refers to the amount of water that is evaporated, transpired, incorporated into products or crops, or otherwise removed from the immediate water environment (Kenny et al. 2009). Both water withdrawal and consumption values are important indicators for water managers determining power plant impacts and vulnerabilities associated with water resources; these metrics need to be considered in relation to existing water resources.

Electricity sector freshwater withdrawals and consumptive uses can be reduced through choices in energy source, cooling system technology, and water source. Certain types of energy sources used to produce electricity, in particular non-thermal renewable energy sources such as photovoltaic (PV) and wind technologies, require little to no water use for operations (Macknick et al. 2012a). Other types of fuels, such as natural gas, can be combusted in higher efficiency configurations such as a combined cycle power plant, which have lower water use requirements than facilities using other fuels, such as coal and nuclear power plants (Grubert et al. 2012). The use of recirculating cooling systems can reduce water withdrawals when compared with oncethrough cooling systems, although available data indicate water consumption and costs are higher (Macknick et al. 2012a). Dry cooling technologies can substantially reduce operational water requirements over both recirculating and once-through cooling systems, but have higher capital costs and are less efficient (Environmental Protection Agency 2011). Lastly, freshwater demands can be greatly reduced by substituting alternative sources of water, such as shallow brackish groundwater or municipal wastewater, although the use of these water sources may also incur additional costs (Tidwell et al. 2013b).

Prior studies have evaluated how the future development of the electricity sector could impact water resources in the United States, but they have done so without considering the feasibility of power plants being located in particular locations (Chandel et al. 2011; Clemmer et al. 2013; Macknick et al. 2012b; Roy et al. 2012; Tidwell et al. 2013a; van Vliet et al. 2012). Electricity capacity expansion models often do not have sufficient geographic resolution in the electricity sector to evaluate water constraints on spatial scales relevant for water resource management, and until recently basin-level data on water availability did not exist for the entire United States.

This analysis provides a description of the first U.S. national electricity capacity expansion model to incorporate water resource availability and costs as a constraint for the future development of the electricity sector. The Regional Energy Deployment System (ReEDS) model was modified to incorporate water resource availability constraints and costs in each of its 134 Balancing Area (BA) regions along with differences in costs and efficiencies of cooling systems. Water resource availability and cost data are from recently completed research at Sandia National Laboratories (Tidwell et al. 2013b). Scenarios analyzed include a business-as-usual 
scenario without water constraints as well as four scenarios that include water constraints and allow for different cooling systems and types of water resources to be utilized. This analysis provides insight into where water resource constraints could affect the choice, configuration, or location of new electricity technologies. 


\section{Methods}

The authors modified the ReEDS model to incorporate water resource availability constraints and costs in the model. Consideration of water resources as a constraint for electric sector capacity expansion required three primary analytical tasks: modification of the ReEDS model to incorporate water-related availability and technological constraints, development of water resource availability and cost estimates at a regional scale adaptable to the ReEDS regions, and development of scenarios to test model capabilities and results.

\subsection{ReEDS Model Modifications}

ReEDS model description: The ReEDS model estimates the types and locations of future electricity generation and transmission capacity expansion along with seasonal and diurnal electricity dispatch over the period 2010-2050 (Short et al. 2011). All major generating technologies are represented, including coal, natural gas combined cycle (GasCC), natural gas combustion turbine (GasCT), nuclear, hydro, wind, solar, geothermal, biopower, and storage. Generation capacity must meet requirements for regional electricity demand, operating reserves, and planning reserves. Spatial resolution is high for a capacity expansion model; electricity demand is satisfied in 134 BAs connected by an aggregated transmission system of $\sim 300$ lines, and wind and solar resources are defined in 356 resource regions. ReEDS uses a simplified dispatch that optimizes power output and operating reserves in 17 "slices" of time that represent demand throughout the year, including four for each season and one "superpeak" representing the top 40 hours of demand in a year. ReEDS can also incorporate existing energy policies such as state renewable portfolio standard (RPS) requirements or carbon targets.

ReEDS has been utilized for a variety of electricity system analyses examining high regional and national penetration of different types of renewable resources, impacts of natural gas price fluctuations, as well as for impacts of clean energy scenarios on water resources (Clemmer et al. 2013; Department of Energy 2008; Logan et al. 2013; Macknick et al. 2012b; National Renewable Energy Laboratory 2012; Tidwell et al. 2013a).

For this analysis, the ReEDS model was modified to 1) incorporate cost, performance, and water use characteristics of different fuel technology and cooling system combinations and 2) include consideration of water resource availability as a necessary condition for new power plant construction.

Incorporation of cooling system characteristics: Cooling systems implemented in the ReEDS model fall into four categories: once-through, pond, recirculating, and dry cooling systems. Individual power plant cooling systems are derived from a database developed by the Union of Concerned Scientists (Union of Concerned Scientists, 2012). Within each ReEDS BA, existing generation capacity by power generation technology is disaggregated into power-cooling system technology categories based on 2008 generation data from the database. In cases where the database does not contain information on cooling systems for certain fuel types within a particular BA, the cooling system makeup for the fuel-type with most generation in that BA is applied.

Cooling systems have different capital and O\&M costs, and different performance and water use characteristics that can affect economic decisions on where to build certain types of power 
plants. The authors reviewed recent literature and available data on differences in cost and performance characteristics of different cooling systems in new power plants (Woldeyesus, Macknick, and Colman, forthcoming). In general, among all cooling system types, once-through cooling systems are the least expensive and have the highest efficiencies. Recirculating cooling systems generally have higher capital and operating costs and are less efficient than oncethrough cooling systems, but are less expensive and more efficient than dry cooling systems. Pond-cooled systems have a variety of configurations that can resemble either recirculating or once-through systems, and generally have water use characteristics that fall in between those of recirculating and once-through systems.

Baseline input data to the ReEDS model provides cost and performance information for new power plants assuming they are built with recirculating cooling systems (Black \& Veatch 2012). The ReEDS model then uses a series of cost and performance multipliers to modify cost and performance input data for new capacity built with other cooling system types (Woldeyesus, Macknick, and Colman, forthcoming). The model retains the flexibility to utilize region- and time-specific input data multipliers for cooling system cost and performance characteristics.

Water withdrawal and consumption rates for power technology-cooling system combinations are defined in terms of volumes of water withdrawn and consumed per unit of electricity generation (i.e., gallons per MWh of electricity generated) (Macknick et al. 2012a). BA-specific values are applied to each BA region based on climatic conditions that can affect power plant water withdrawal and consumption rates (Woldeyesus et al., forthcoming).

Consideration of water resource availability and costs: Water availability constraints were implemented in the model for each BA region. Sufficient water access must be purchased to satisfy the withdrawal requirements of the fuel technology-cooling system combination and the size of the facility, in order for a new power plant to be built. Sufficient water access is defined as enough water for a power plant to operate at full capacity at any time throughout the year. This conservative method ensures new power plant builds have secured more than enough water than they would realistically use in a year so that they can operate at maximum output during the annual low-flow condition. The ReEDS model calculates actual water withdrawals and consumption separately from the purchases of water access based on the actual operation of the power fleet. It is important to distinguish between constraining water access, which affects capacity expansion only, and constraining physical water availability, which would influence operation. Physical water availability constraints in ReEDS are the subject of ongoing work.

Each BA has unique water access availability and cost for up to five resource categories: unappropriated freshwater, appropriated freshwater, fresh groundwater, brackish groundwater, and wastewater. Multiple types of water resources can be purchased to meet the demand for new generation capacity. Water access availability of retiring power plants is returned to the pool of available water access for new power plants at the price of appropriated water access.

The ReEDS model identifies lowest-cost solutions for new capacity builds; in cases where there is insufficient freshwater available, the ReEDS model could construct the same configuration of power plant but at a smaller capacity, select an alternative cooling system, select alternative water resource types, construct a less water-intensive power technology-cooling system 
combination in the same location, or construct a power plant and additional transmission in a different location.

\subsection{Water Availability and Cost Data}

Water access availability data was developed in partnership with Sandia National Laboratories (Tidwell et al. 2013b). Five types of water resources are individually considered, under the categories of unappropriated surface water, unappropriated groundwater, appropriated water (western U.S. only), municipal wastewater and brackish groundwater. Water availability metrics also incorporate projected growth in non-thermoelectric water demand to 2035 to provide an indication of future water availability, given competing demands. No attempt is made to model changes in precipitation, water flows, or potential changes in water resources due to climate change.

Each of the five sources of water has costs for utilizing that particular supply that can vary geographically. Efforts were made to establish a consistent and comparable measure of cost to deliver water of potable quality to the electric sector. Cost categories include capital and O\&M costs. Capital costs include the purchase of water access as well as the construction of groundwater wells, conveyance pipelines, and water treatment facilities, as necessary. All capital costs are amortized over a 30-year horizon and assume a discount rate of $6 \%$. O\&M costs include expendables (e.g., chemicals, membranes), labor, and waste disposal, as well as the energy to lift, move, and treat the water (assumed $\$ 0.35 / \mathrm{kWh}$ ).

The 6-digit HUC (Hydrological Unit Code) spatial resolution was used in this analysis (Seaber et al. 1987). Because of the different spatial resolution between the HUCs and ReEDS BA regions, a spatial weighting calculation was made to apportion the water from the watershed unit to each BA. This procedure apportioned a percentage of the water in each 6-digit HUC to each BA by assuming water is directly correlated to total BA area within that HUC. Figure 1 highlights 6digit HUC regions and BA regions.

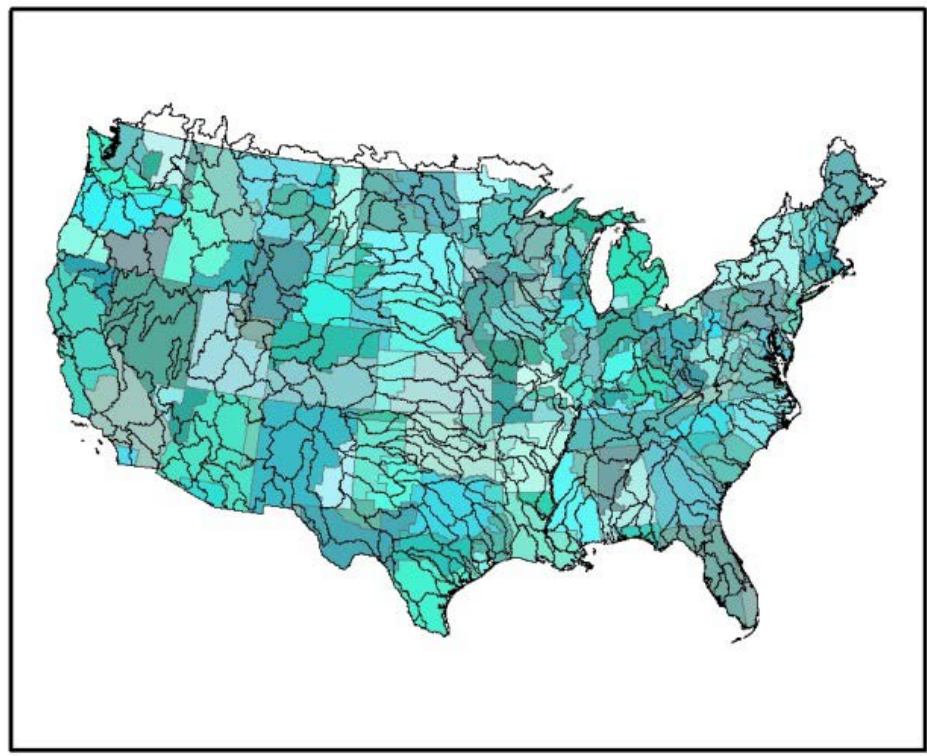

Figure 1. ReEDS BA regions (colors) and 6-digit USGS HUC regions (black outlines) 
Unappropriated surface water: This source of water is the portion of fresh surface water for which a state will issue a permit or water right for future development. Unappropriated surface water volumes are taken from state estimates throughout the West. Estimates of available unappropriated surface water are based on years with normal streamflow, with an implied use of storage for low flow years. For eastern states, where water rights regimes differ and there are no official unappropriated water rights, environmental flow considerations are used to define unappropriated surface water availability, with a conservative threshold of maintaining streams at a minimum of $50 \%$ of annual average flows to define unappropriated surface water available for use in the electric sector.

No costs are assigned to unappropriated surface water. It is recognized that there are costs associated with constructing intake structures and permitting. Such costs are not considered, in part because of the wide range of variability across use types and location. More importantly, similar intake and permitting costs will be realized with all five sources of water, so estimating these uncertain costs has little value to this effort.

Unappropriated groundwater: This source of water addresses available fresh groundwater for which a state will issue a permit or water right for development. A simple water balance approach was adopted to identify potable groundwater that is potentially available for use in the electricity sector, as state estimates are largely lacking. Available unappropriated groundwater is set equal to the difference between annual average recharge and annual groundwater pumping. Further restrictions on unappropriated groundwater availability are introduced in watersheds located within state-defined groundwater protection zones, watersheds with significant groundwater depletions, and watersheds with $10 \%$ or less of their land area underlain by a principal aquifer.

Estimated costs consider both capital and O\&M costs to lift water for use. Depth to groundwater is taken from USGS well-log data averaged at the county level, and capital costs for drilling are estimated along with electricity to lift water following the approach outlined in Watson and others (Watson et al. 2003).

Shallow brackish groundwater: Brackish water availability is limited to resources no deeper than 2,500 feet and salinities below 10,000 total dissolved solids (TDS). Deeper, more concentrated resources would generally be very expensive to exploit. Full coverage of the United States requires the use of multiple sources of information, including state-level data from Texas, New Mexico, and Arizona; USGS estimates of existing usage; and the National Water Information System (NWIS) database. To avoid brackish water that is in contact with potable streamflow, availability is set to zero when the average depth to brackish water is less than 15 meters (50 feet) and the salinity is less than 3000 TDS.

Estimated costs consider both capital and O\&M costs to capture and treat the brackish groundwater. Cost calculations follow standards outlined in the Desalting Handbook for Planners (Watson et al. 2003). Capital costs include expenses to drill and complete the necessary groundwater wells and construct a treatment plant utilizing reverse osmosis. The number of wells needed and treatment plant capital costs are based on the treated volume of water, which is assumed to be five million gallons per day. Other key design parameters include the depth of the brackish water and TDS. The data are then averaged at the county level. 
Municipal wastewater: Municipal wastewater is rapidly being considered as an alternative source of water for new energy development, particularly in arid regions (Stillwell and Webber, 2014) (Li et al. 2011). Municipal wastewater discharge data are consistently available throughout the country from EPA and USGS sources. A considerable fraction of wastewater discharge is currently re-used by industry, agriculture, and thermoelectric generation. Re-use estimates from available data sources are subtracted from the projected discharge values. In western states, the availability of municipal wastewater must consider return flow credits. Municipalities that discharge to perennial streams receive return flow credits for treated wastewater. This water is not available for new development as it is already being put to use downstream.

Estimated costs consider expenses to lease the wastewater from the municipality, convey the water to the new point of use, and to treat the wastewater. Fees charged to lease treated wastewater from the municipality were estimated based on the initial work of the Electric Power Research Institute (Electric Power Research Institute 2008). As no geospatial or plant-related trends were noted in the pricing, an average of the reported fees was adopted for this study, which was calculated at $\$ 400$ per acre-foot of water.

Conveyance of treated wastewater from the treatment plant to the point of use is a potentially important cost. Both capital construction costs for a pipeline and O\&M costs principally related to electricity for pumping are considered, consistent with Watson and others (Watson et al. 2003). It is assumed that all wastewater must be treated to advanced standards before it can be re-used. This conservative assumption was adopted considering both realized improvements in downstream operations (e.g., increased cycles of use, reduced scaling, improved feed quality) and the current trend of regulation toward requiring advanced treatment (Electric Power Research Institute, 2008). Associated O\&M costs consider expenses for electricity, chemicals, and labor.

Appropriated water: Appropriated water access includes resources that could be made available for new development by abandonment and transfer of a water right. Only states that govern water according to the doctrine of prior appropriation (i.e., western states) issue transferrable water rights. As such, this water source is only applied to western states. Water transfers have traditionally involved sales of water rights from irrigated farm land to urban uses. The potential for such transfers is estimated based on the irrigated acreage in a given watershed that is devoted to low-value agricultural production, specifically irrigated hay and alfalfa. Land abandonment is limited to $5 \%$ of the total irrigated acreage in the watershed. For watersheds experiencing significant groundwater depletions, available appropriated water is reduced by $50 \%$.

Water access transfer costs are based on historical data collected by the Water Strategist and its predecessor the Water Intelligence Monthly. Costs are estimated by state because of the limited data availability. Recorded transfers are averaged by year and by state, and the average of the last 5 years is used for purposes of this study. Data are only available for 12 western states: Arizona, California, Colorado, Idaho, Montana, Nevada, New Mexico, Oregon, Texas, Utah, Washington, and Wyoming. Historical prices may not reflect future prices, and no attempt was made to estimate future market dynamics.

Figures 2 and 3 show water availability and cost metrics, respectively, at the ReEDS BA level. Further information, including a full treatment of source data and methods for developing water availability metrics, can be found in Tidwell and others (Tidwell et al. 2013b). 


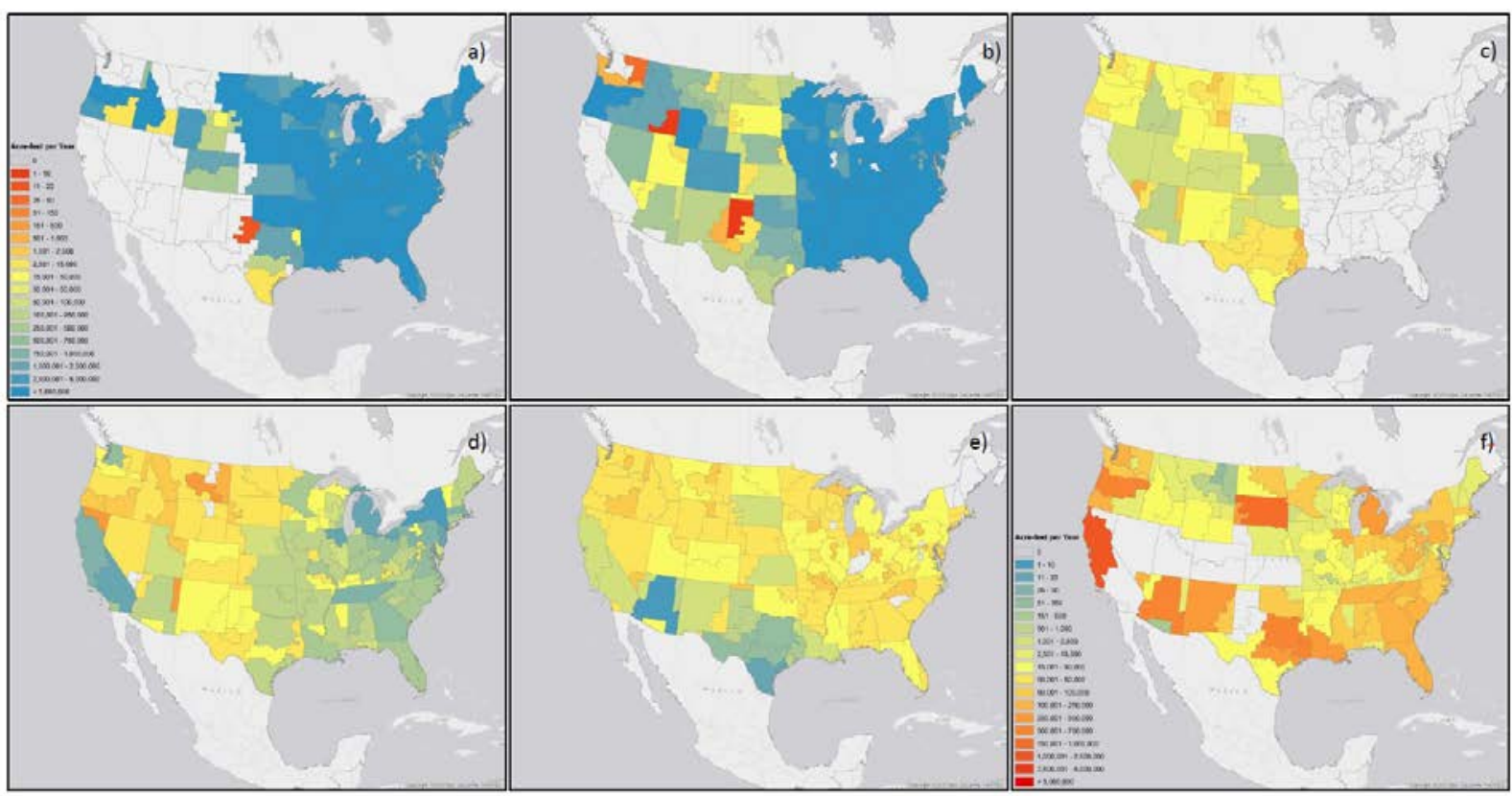

Figure 2. Water availability and future demand at the ReEDS BA level (Tidwell et al. 2013b)

Water availability metrics for a) unappropriated surface water, b) unappropriated groundwater, c) appropriated water, d) municipal wastewater, e) brackish groundwater, and f) projected increase in consumptive water use between 2005 and 2035. All are mapped to a consistent non-linear color scale; however the color scheme is reversed between availability and demand (e.g., hot colors indicate limited availability or high demand).

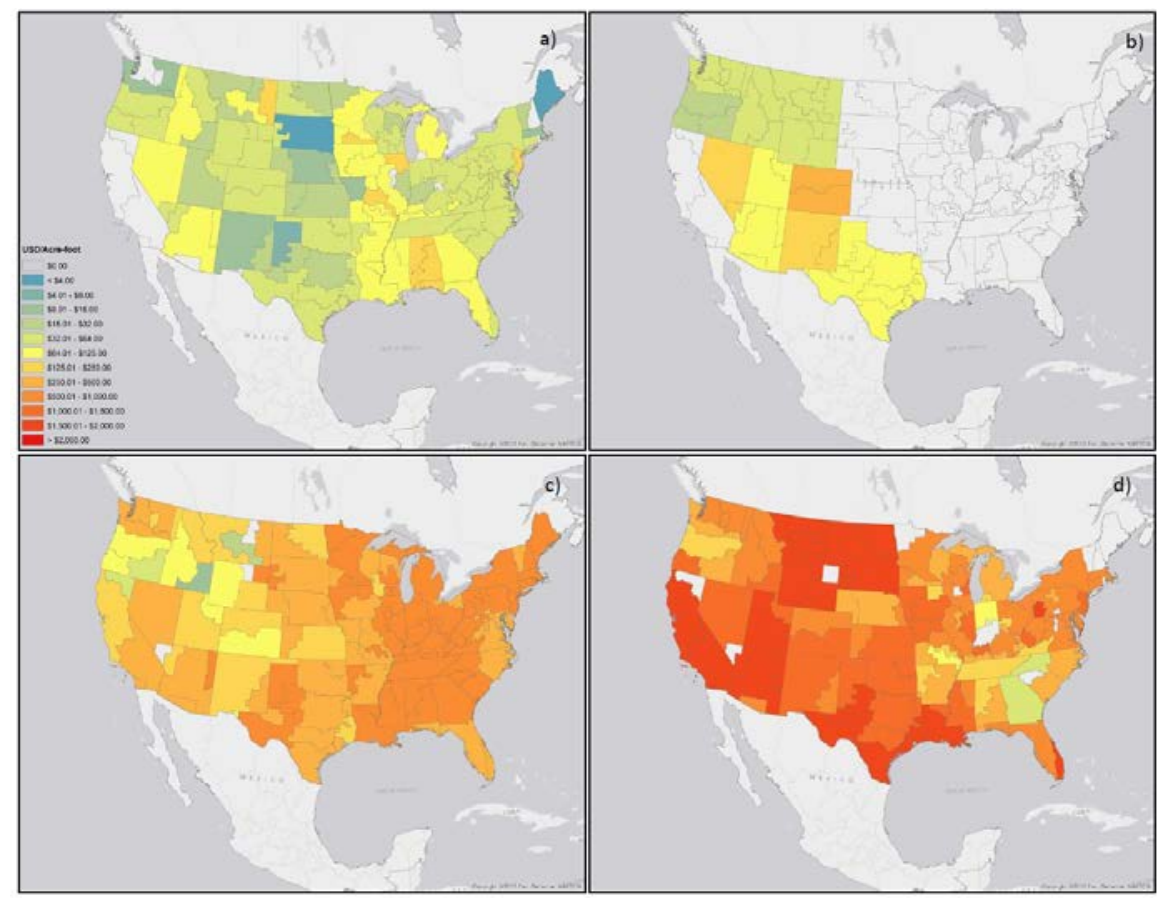

Figure 3. Water cost at the ReEDS BA level (Tidwell et al. 2013b)

Mapped are water cost metrics (U.S. dollars per acre-foot of water) for a) unappropriated groundwater, b) appropriated water, c) municipal wastewater, and d) brackish groundwater. All are mapped to a consistent non-linear color scale. 


\subsection{Other Key ReEDS Data and Assumptions}

Input data: The ReEDS input data and assumptions implemented in this analysis are the same as those in the Wind Vision (WV) report (Department of Energy 2015). Technology cost and performance estimates primarily use U.S. Energy Information Administration (USEIA) Annual Energy Outlook (AEO) 2014 reference projections (Energy Information Administration (EIA) 2014). Transmission cost and financing assumptions are identical to WV. Natural gas, coal, and uranium price projections are also defined using the USEIA AEO 2014 report (Energy Information Administration (EIA) 2014).

Wind resource estimates are derived from WV and use current and future costs based on recent industry trends (Department of Energy 2015). Solar resources are also based on WV. Their capital costs are decreasing, following current industry trends and expectations, and are anticipated to continue to decline during the approach to $62.5 \%$ of SunShot Vision cost goals by 2020 and $75 \%$ of SunShot Vision cost goals by 2040 before remaining constant thereafter (Department of Energy 2012). Geothermal resources are identical to WV, and biomass resources are based on the Billion Ton Update study (Department of Energy 2011). Hydropower resources have been updated to include resource assessments from Oak Ridge National Laboratory (ORNL) and a cost model from Idaho National Laboratory (Hadjerioua et al. 2012; Hall et al. 2003; Kao et al. 2014).

Retirements of nuclear- and fossil-based facilities are based on proposed and lifetime retirements identified by Ventyx and M.J. Bradley along with capacity factor-based coal retirements, where coal-fired installations that operate below a certain capacity factor threshold are retired (Saha 2013; Ventyx 2013).

Scenario Analysis: Six scenarios from 2010 to 2050 were analyzed to demonstrate new capabilities of the ReEDS model with water constraints. Scenarios were developed to highlight the effect water availability and cooling technology restrictions can have on national and regional technology deployment and water usage. A business-as-usual (or NR-O, for No Rights constraint, Once-through cooling allowed) scenario includes no consideration of water access rights constraints or restriction on cooling technologies. The five other scenarios include water access rights constraints, with differing categories of water access and cooling system technologies available. AR-O allows all available water access rights and all cooling system technologies. AR-NO allows all available water access rights, but no new once-through cooling systems can be installed on new power plants. LR-O allows once-through cooling systems but considers only a limited set of water resources, excluding fresh unappropriated, appropriated, and fresh groundwater resources. LR-NO considers the same limited set of water resources but also prohibits new once-through cooling systems. Table 1 shows the scenarios considered. 
Table 1. Scenario Matrix Considered in this Analysis

\begin{tabular}{|l|l|l|l|}
\hline Scenario & $\begin{array}{l}\text { Water } \\
\text { Access } \\
\text { Rights } \\
\text { Constraint? }\end{array}$ & $\begin{array}{l}\text { Access } \\
\text { Rights } \\
\text { Available }\end{array}$ & $\begin{array}{l}\text { Cooling } \\
\text { Technologies } \\
\text { Available }\end{array}$ \\
\hline NR-O & No & N/A & All \\
\hline NR-NO & No & N/A & $\begin{array}{l}\text { No once-through } \\
\text { cooling }\end{array}$ \\
\hline AR-O & Yes & All & All \\
\hline AR-NO & Yes & All & $\begin{array}{l}\text { No once-through } \\
\text { cooling }\end{array}$ \\
\hline LR-O & Yes & Limited & All \\
\hline LR-NO & Yes & Limited & $\begin{array}{l}\text { No once-through } \\
\text { cooling }\end{array}$ \\
\hline
\end{tabular}




\section{Results}

National Electricity Sector Results: Under all six scenarios, electricity capacity grows to more than 1,700 GW, with similar percentages of fuel technologies across scenarios (Figure 4).

Natural-gas combined-cycle (NGCC) power plants provide the plurality of electric capacity by the year 2050. Under NR-NO and NR-O, NGCC capacity is approximately 456 and 479, respectively. Under AR-O, NGCC capacity is $479 \mathrm{GW}$. Other scenarios show similar levels of NGCC capacity in 2050, with LR-O capacity at 469 GW, AR-NO at 457 GW, and LR-NO at 456 GW. The cooling system and water resource constraints lead to slightly lower levels of NGCC capacity on the national level.

Scenarios differ in the types of cooling systems that are built for NGCC plants, with scenarios NR-O, AR-O, and LR-O calling for the building of new power plants with once-through cooling systems that have lower costs and higher efficiencies than power plants with recirculating cooling systems. In LR-O, the limited water resource availability case, approximately $240 \mathrm{GW}$ of NGCC are built by 2050 with recirculating cooling systems rather than once-through cooling systems due to a lack of available water resources. The scenarios that do not allow once-through cooling systems (AR-NO, LR-NO) retain some existing once-through capacity, with new builds primarily utilizing recirculating cooling systems. Water and technology constraints lead to minor increases in capacity builds for low-water technologies such as PV and natural gas combustion turbines.

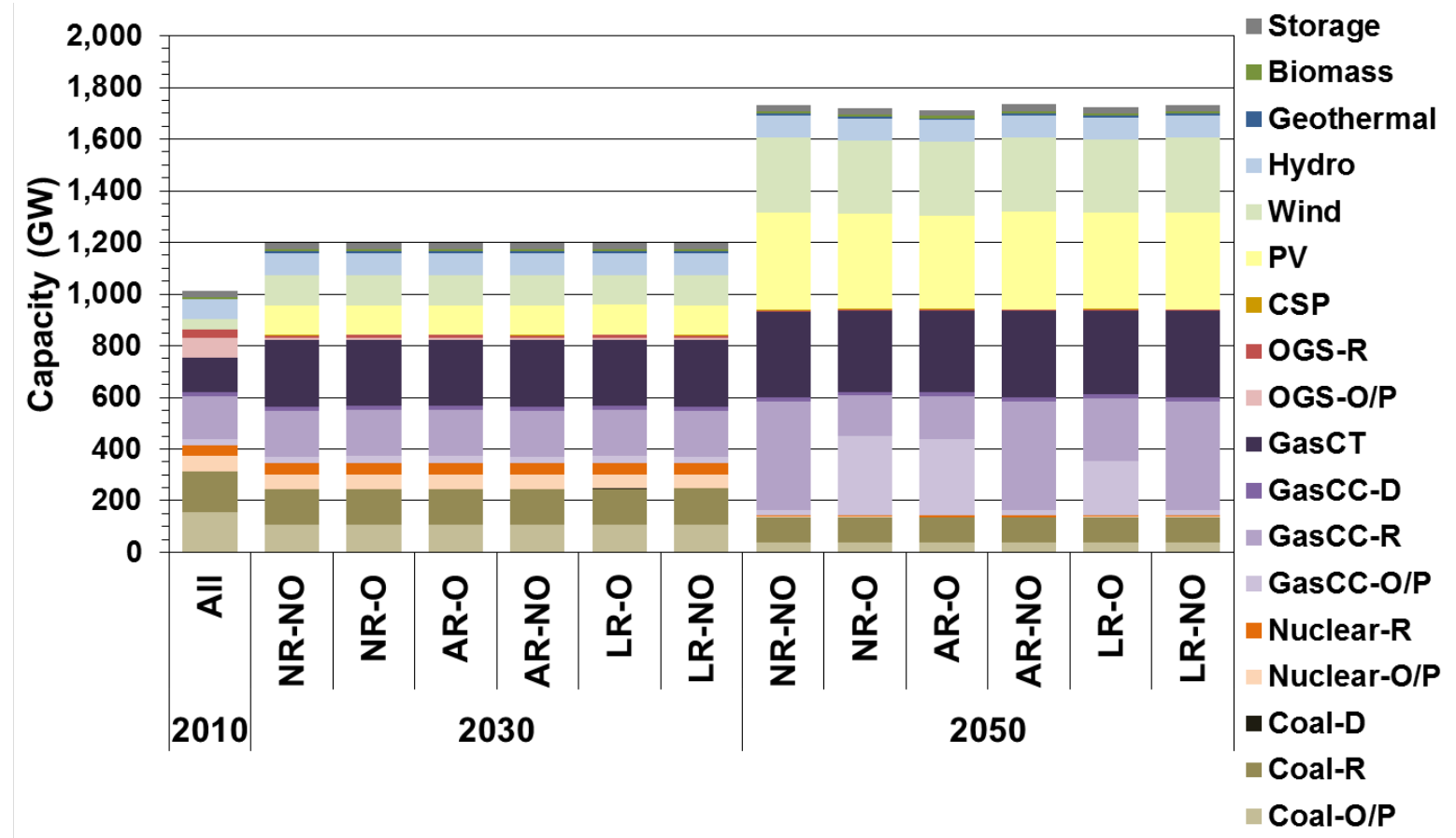

Figure 4. National electricity capacity by fuel type and cooling system in 2030 and 2050

Regional Electricity Sector Results: Despite national similarities in total electricity capacity by 2050, regional differences can be more substantial due to differences in water availability. Regional differences in electricity capacity translate to regional differences in where water withdrawals and consumption occurs. Results indicate that cost advantages of certain types of 
power plants relative to others (e.g., NGCC builds are generally lower cost than other types) are so great that they outweigh the additional costs of constructing new transmission infrastructure to bring electricity from areas of low demand but higher water availability to areas of high demand but insufficient water availability. Examining the regional changes in NGCC construction thus provides insight into where water resource changes have the greatest impact on the development of the electricity sector.

Figure 5 highlights changes in the locations where NGCC capacity is built between NR-O and the four other water-constrained scenarios in 2050.
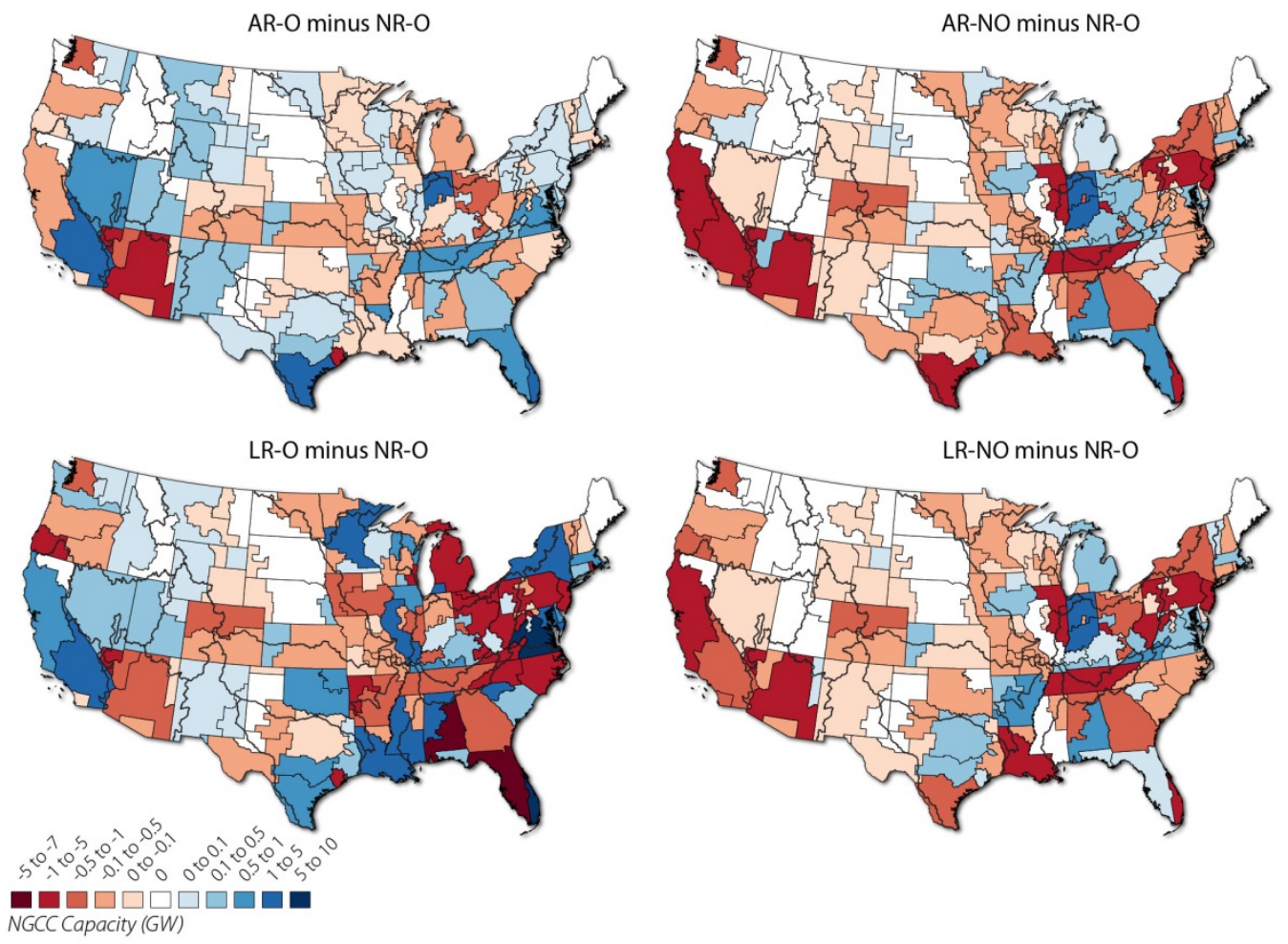

Figure 5. Comparison of NGCC capacity in 2050 between NR-O and AR-O, AR-NO, LR-O, and LR-NO

Red areas indicate locations where NGCC capacity is greater in NR-O than in the water access rights scenario. Blue areas indicate locations where NGCC capacity is greater in the water access rights scenario than in NR-O.

Differences in locations of NGCC capacity highlight the importance of water access and cooling systems on the development of the electricity sector. Although national NGCC capacity in AR-O differs by less than $0.01 \%$ from NR-O in 2050, regional results indicate that more NGCC facilities and capacity are built under NR-O in parts of the southeast, whereas when water access rights are considered, more capacity is built in the northeast, south Texas, and parts of the southwest. These differences are magnified, and sometimes switched, when considering the limited-water-resource scenario that allows once-through cooling (LR-O), which differed in NGCC capacity by $2.2 \%$ in 2050 . Comparing NR-O with LR-O, greater amounts of NGCC capacity are built in NR-O in the southeast, north Texas, and Mid-Atlantic regions. NGCC 
capacity in the water-constrained LR-O case is built in areas near south Texas and the west. Although national estimates of NGCC capacity are similar between NR-O and the scenarios that allow once-through cooling, these national similarities mask the inherent regional differences in where NGCC is most cost-effective to build. Considering the scenarios that do not allow oncethrough cooling (AR-NO, LR-NO, NR-NO) with NR-O, approximately 5.0\% less ( 23 GW) NGCC is built than in NR-O. Much of this capacity in NR-O is built in parts of California, south Texas, Tennessee, and the northeast. NGCC capacity in the once-through limiting scenarios is replaced by increases in low water intensity, natural gas combustion turbine in most regions.

Results indicate that, given current water availability data, limits on water resource availability and cooling systems will not greatly affect the national electricity profile in 2050, yet they could have some important regional implications on energy development and associated water requirements.

Water Results: National water withdrawal and consumption values decline substantially under all scenarios considered, largely due to shift in generating technologies as well as cooling systems. National water withdrawal and consumption values among scenarios in 2050 can be greatly affected by the availability of cooling systems and water resources. Water withdrawals are largest in the unconstrained NR-O case (nearly 24.6 trillion gallons in 2050), followed closely by the scenarios that allowed once-through cooling (AR-O, LR-O). Water withdrawals in the scenarios that did not allow once-through cooling (AR-NO, LR-NO, NR-NO) fell by $67 \%$ (around 16 trillion gallons) in 2050 from the NR-O scenario. However, scenarios that reduced withdrawals led to increases in water consumption. Scenarios that did not allow once-through cooling resulted in a 14-16\% increase (149-156 billion gallons) in water consumption over the NR-O scenario in 2050. Table 2 highlights differences in withdrawals and consumption in 2050 among the different scenarios.

Table 2. Water Withdrawals and Consumptive uses in 2050

\begin{tabular}{|l|l|l|}
\hline Scenario & $\begin{array}{l}\text { Withdrawals (2050) } \\
\text { Trillion Gallons }\end{array}$ & $\begin{array}{l}\text { Consumption (2050) } \\
\text { Trillion Gallons }\end{array}$ \\
\hline 2010 & 41.6 & 1.7 \\
\hline NR-O & 24.6 & 1.0 \\
\hline NR-NO & 8.2 & 1.1 \\
\hline AR-O & 23.7 & 1.0 \\
\hline AR-NO & 8.3 & 1.1 \\
\hline LR-O & 19.1 & 1.0 \\
\hline LR-NO & 8.3 & 1.1 \\
\hline
\end{tabular}

Much like NGCC capacity results, regional water withdrawal and consumption values can differ greatly from national trends. Figure 6 shows water withdrawals in 2050 for four scenarios compared with NR-O. 

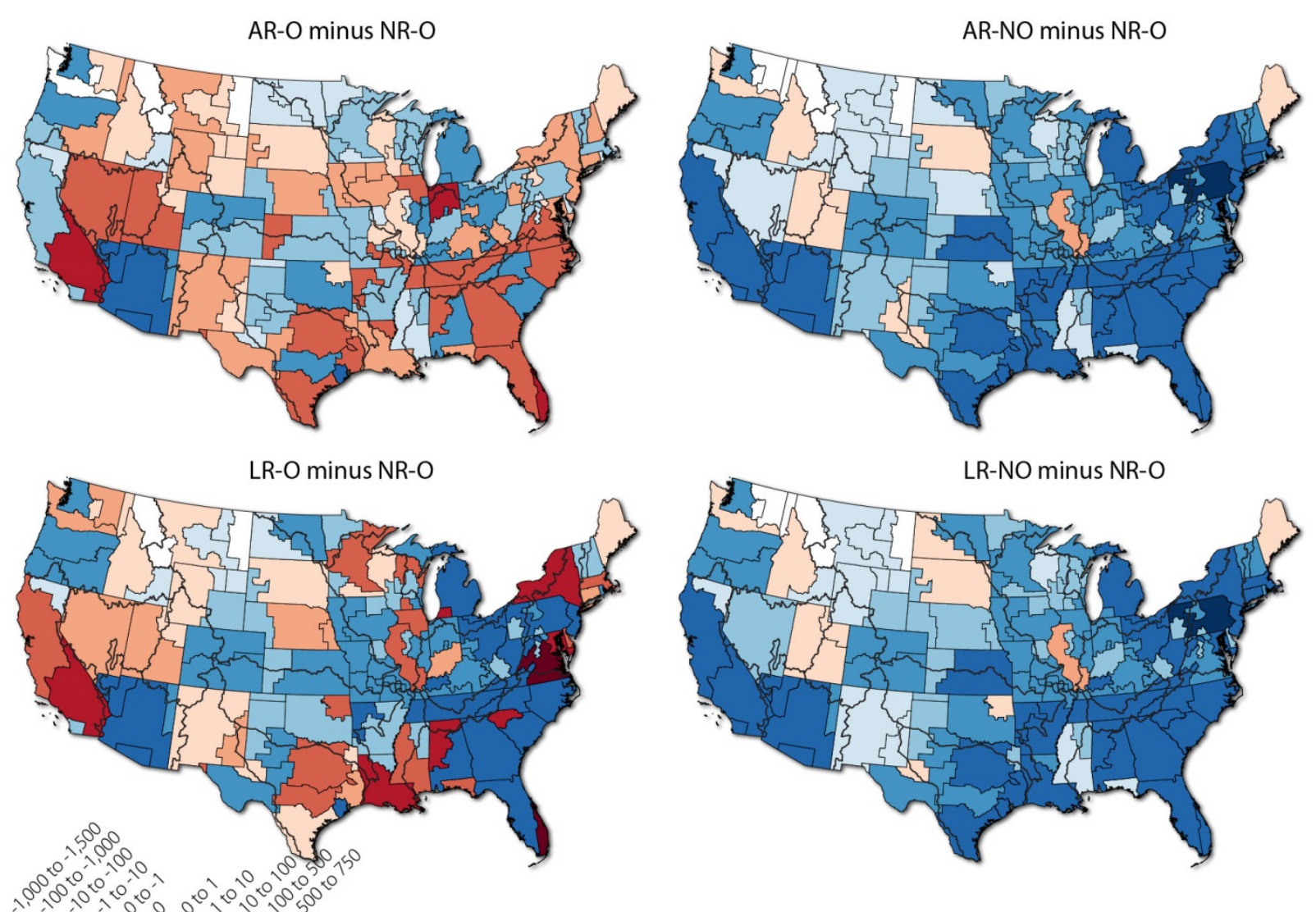

$\square \square \square \square \square \square \square \square \square \square \square$

Billions of Gallons

Figure 6. Comparison of water withdrawals in 2050 between NR-O and AR-O, AR-NO, LR-O, and LR-NO

Red areas indicate locations where withdrawals are greater in the water access rights scenarios than in NR-O. Blue areas indicate locations where withdrawals are less in the water access rights scenarios than in NR-O.

Regional impacts in water withdrawals are diverse. Some regions show large variations in water withdrawals depending on the particular scenario. For example, in Tennessee, Georgia, and Florida, withdrawals are greater in AR-O than in the unconstrained NR-O case, yet are lower than NR-O for all other scenarios. Other regions show consistently higher or lower withdrawals than NR-O, regardless of scenario. For example, withdrawals in NR-O are consistently higher than water scenarios for parts of Arizona, Michigan, Oregon, and Nebraska, whereas withdrawals in NR-O are consistently lower than water scenarios for parts of Utah and the upper Northeast.

The results of regional water consumption mirror the results of withdrawal in many, but not all, cases. For many regions, as withdrawal declines, consumption increases. Figure 7 highlights regional changes in water consumption in 2050 between NR-O and water scenarios. 

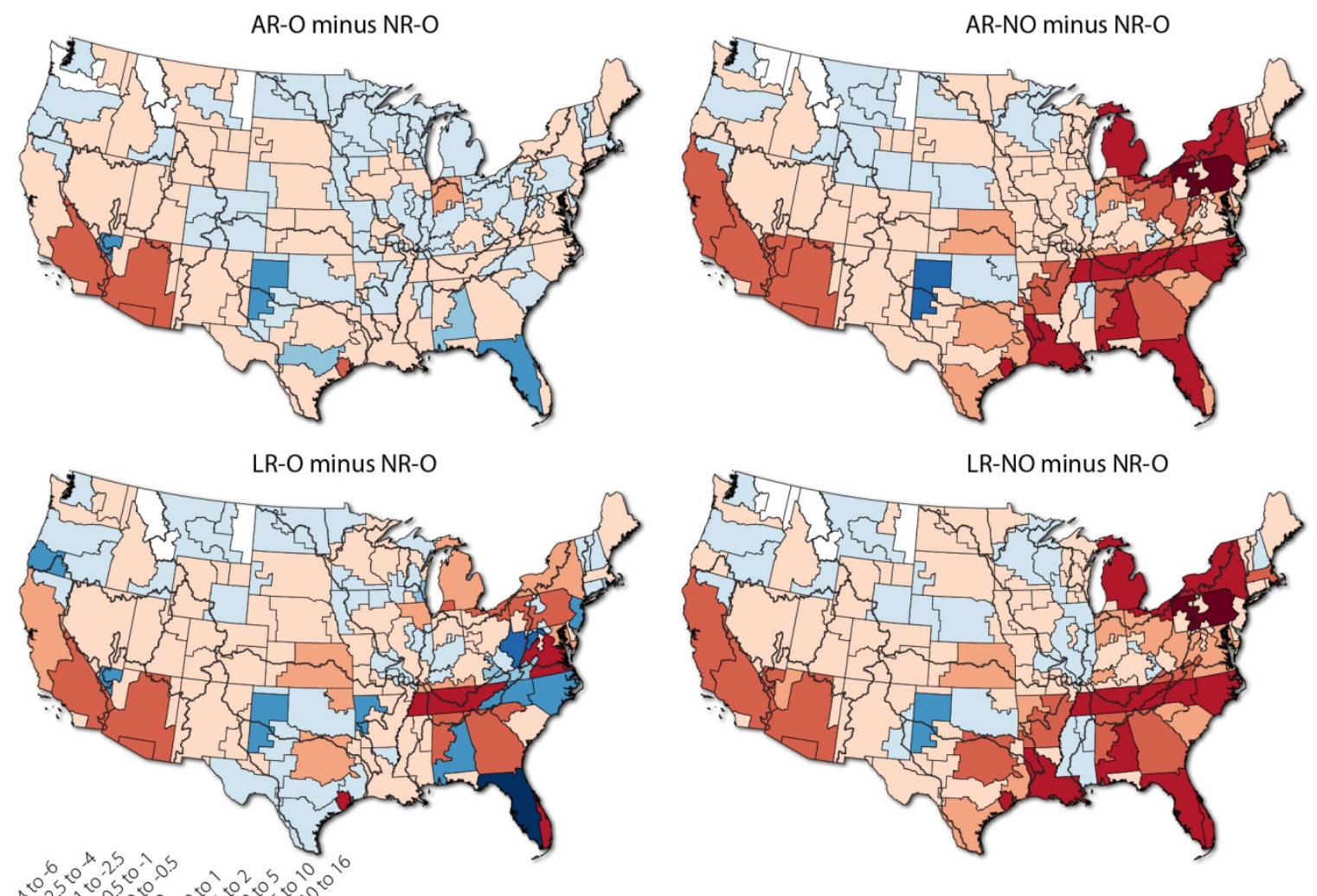

口曰 $\square \square \square \square \square \square \square \square$

Billions of Gallons

\section{Figure 7. Comparison of water consumption in 2050 between NR-O and AR-O, AR-NO, LR-O, and LR-NO}

Red areas indicate locations where consumption is greater in the water access rights scenarios than in NR-O. Blue areas indicate locations where consumption is less in the water access rights scenarios than in NR-O.

In general, water consumption in 2050 for NR-O is lower nationally and in most regions than the other water scenarios. Certain regions, such as Oklahoma, Montana, and Oregon, show lower levels of water consumption than NR-O under all scenarios.

Results suggest that because of the water use characteristics of once-through systems compared with recirculating systems, policies that limit withdrawals might lead to increases in energy sector water consumption in certain regions. 


\section{Discussion}

Results presented here provide the first documented case of a national-level, electric sector capacity expansion model incorporating water availability endogenously as a constraint for future electricity sector development. Analysis of water constraints and impacts in capacity expansion models was limited in the past due to the lack of water-availability data and a model with sufficient spatial resolution to capture the important regional differences in water availability. The purpose of this work is to highlight the new capability of this model and the potential impact on the electricity sector of scenarios that alter the availability of certain types of water resources and policies that affect the types of cooling systems that can be utilized. Rather than just indicating potential risks or threats to water resources without considering the likelihood of new generation being built in certain locations, this work provides a more accurate assessment of where future types of electricity development will occur given indicators of water availability.

An important and unique result from the scenario analysis is the demonstration that available water resources and cooling system technology limitations can affect the location and type of power plants that are built in the United States. Water availability restrictions considered in these scenarios do not substantially alter the national trends in the electricity sector towards higher penetrations of natural gas and renewable technologies while coal-fired and nuclear power plants are retired. This result suggests that although many low carbon technologies (e.g., wind, PV) have low water intensities, water policies on their own are likely to have a minor impact on national greenhouse gas emissions. Results also indicate that, at current prices of water and energy technologies, it can be economically advantageous to build water-intensive power plants in certain locations where there is water rather than build power plants with lower water intensities in locations with water scarcity. Future changes in energy technology costs, cooling technology costs, water costs, or transmission costs could affect these decisions. The diversity of impacts and capacity change locations highlights the fact that power-plant build decisions must take into consideration a variety of different factors, one of which is water.

Although this effort demonstrates a novel capability that can be used for a variety of different policy and energy system analyses, certain limitations in the model are acknowledged and serve as areas of further research and model development. Despite the high spatial resolution of the ReEDS model, the BA regions do not always correspond well with watershed regions, which means that actual water availability within a specific BA region is not uniform because it is modeled in ReEDS. Thus ReEDS could overestimate water availability for a BA region by assuming water resources of the same type in that BA are readily available for a single capacity addition. In addition, the model evaluates the availability of water for new capacity additions, but does not restrict the operations of existing power plants that have defined water access due to drought-related water shortages or temperature constraints. Lastly, the model considers annual water availability, whereas actual water availability can change on a seasonal basis. The authors are undertaking efforts to address these limitations in future versions of the ReEDS model. 


\section{Summary}

The results presented here highlight the importance of water resource spatial variability in the development of the electricity sector. This work, by adding in water availability constraints endogenous to the model itself, improves upon prior studies that have only shown probable water impacts of electricity sector development. This model provides electricity sector and water usage results at a spatial scale that can be analyzed with a variety of water stress metrics.

The modified ReEDS model provides a unique platform for future energy system, water resource, and policy analysis. Different energy technologies can have vastly different water requirements, with some low carbon energy technologies (e.g., wind, PV) having the lowest water intensity, whereas other low carbon energy technologies (e.g., nuclear, wet-cooled concentrating solar power, fossil-fuels with carbon capture and sequestration) having the highest water intensity in the electricity sector. A variety of energy scenarios could be evaluated to assess the degree to which water constraints affect deployment and system costs. In addition, scenarios could evaluate how different energy system pathways respond to changes in water availability that might result from long-term droughts or climate change. Lastly, a variety of policies could be analyzed, specifically as they relate to energy policy, water management policy, and cooling system policy. Such analyses could provide greater insight into the feasibility, cost, energy system, and water resource impacts of proposed policies. 


\section{References}

Averyt, K.; Fisher, J.; Huber-Lee, A.; Lewis, A.; Macknick, J.; Madden, N.; Rogers, J.; Tellinghuisen, S. (2011). Freshwater Use by U.S. Power Plants: Electricity's Thirst for a Precious Resource. |Cambridge, MA: UCSUSA.

Black \& Veatch. (2012). Cost Report: Cost and performance data for power generation technologies. Overland Park, KS: Black \& Veatch.

Chandel, M.K.; Pratson, L.F.; Jackson, R.B. (2011). "The potential impacts of climate-change policy on freshwater use in thermoelectric power generation." Energy Policy 39; pp. 6234-6242.

Clemmer, S.; Rogers, J.; Sattler, S.; Macknick, J.; Mai, T. (2013). "Modeling low-carbon US electricity futures to explore impacts on national and regional water use." Environ. Res. Lett. 8; 015004.

Department of Energy. (2008). 20\% Wind Energy by 2030: Increasing Wind Energy's Contribution to U.S. Electricity Supply. DOE/GO-102008-2567. Washington, D.C.: DOE.

Department of Energy. (2011). U.S. Billion-Ton Update: Biomass Supply for a Bioenergy and Bioproducts Industry. Oak Ridge, TN: U.S. Department of Energy.

Department of Energy. (2012). SunShot Vision Study. Washington, D.C.: DOE.

Department of Energy. (2013). U.S. Energy Sector Vulnerabilities to Climate Change and Extreme Weather. DOE/PI-0013. Washington, D.C.: DOE.

Department of Energy. (2015). Wind Vision: A New Era for Wind Power in the United States. DOE/GO-102015-4557. Washington, D.C.: DOE.

Electric Power Research Institute. (2008). Use of Alternate Water Sources for Power Plant Cooling. 10014935. Palo Alto, CA: Electric Power Research Institute.

Energy Information Administration (EIA). (2014). Annual Energy Outlook 2014 with Projections to 2040. Washington, D.C.: U.S. Energy Information Administration.

Energy Information Administration (EIA). (2011). Environmental and Economic Benefits Analysis for Proposed Section 316(b) Existing Facilities Rule. EPA 821-R-11-002. Washington, D.C.: EIA.

Grubert, E.A.; Beach, F.C.; Webber, M.E. (2012). "Can switching fuels save water? A life cycle quantification of freshwater consumption for Texas coal- and natural gas-fired electricity." Environ. Res. Lett. 7; 045801.

Hall, D.; Hunt, R.; Reeves, K.; Carroll, G.( 2003). Estimation of Economic Parameters of U.S. Hydropower Resources. INEEL/EXT-03-00662. Idaho Falls, ID: Idaho National Engineering and Environmental Laboratory. 
Kao, S.; McManamy, R.; Stewart, K.; Samu, N.; Hadjerioua, B.; DeNeale, S.; Yeasmin, D.; Fayzul, M.; Pasha, K.,; Oubeidillah, A.,; Smith, B. (2014). New stream-reach development: a comprehensive assessment of hydropower energy potential in the United States. ORNL/TM2013/514. Oak Ridge, TN: Oak Ridge National Laboratory.

Kenny, J.F.; Barber, N.L.; Hutson, S.S.; Linsey, K.S.,; Lovelace, J.K.; Maupin, M.A. (2009). Estimated Use of Water in the United States in 2005. No. CIR - 1344. Reston, VA: United States Geological Survey.

Li, H.; Chien, S.-H.; Hsieh, M.-K.; Dzombak, D.A.; Vidic, R.D. (2011). "Escalating Water Demand for Energy Production and the Potential for Use of Treated Municipal Wastewater."Environ. Sci. Technol. 45, 4195-4200. doi:10.1021/es1040305.

Logan, J.; Lopez, A.; Mai, T.; Davidson, C., Bazilian, M., Arent, D., 2013. Natural gas scenarios in the U.S. power sector. Energy Econ. 40, 183-195. doi:10.1016/j.eneco.2013.06.008

Macknick, J., Newmark, R., Heath, G.; Hallett, K.C. (2012a). "Operational water consumption and withdrawal factors for electricity generating technologies: a review of existing literature." Environ. Res. Lett. 7, 045802. doi:10.1088/1748-9326/7/4/045802.

Macknick, J.; Sattler, S.; Averyt, K.; Clemmer, S.; Rogers, J. (2012b). "The water implications of generating electricity: water use across the United States based on different electricity pathways through 2050." Environ. Res. Lett. 7, 045803. doi:10.1088/1748-9326/7/4/045803.

National Renewable Energy Laboratory. (2012). Renewable Electricity Futures Study. No. NREL/TP-6A20-52409. Golden, CO: National Renewable Energy Laboratory.

Rogers, J.; Averyt, K.; Clemmer, S.; Davis, M.; Flores-Lopez, F.; Kenney, D.; Macknick, J.; Madden, N.; Meldrum, J.; Sattler, S.; Spanger-Siegfried, E.; Yates, D. (2013). Water-Smart Power: Strengthening the U.S. Electricity System in a Warming World. UCSUSA.

Roy, S.B.; Chen, L.; Girvetz, E.H.; Maurer, E.P.; Mills, W.B.; Grieb, T.M. (2012). "Projecting Water Withdrawal and Supply for Future Decades in the U.S. under Climate Change Scenarios." Environ. Sci. Technol. 46, 2545-2556. doi:10.1021/es2030774.

Saha, A. (2013). Review of Coal Retirements. M.J. Bradley \& Associates LLC.

Seaber, P.R.; Kapinos, F.P.; Knapp, G.L. (1987). Hydrologic unit maps. No. WSP - 2294. Reston, VA:United States Geological Survey.

Short, W.; Sullivan, P.; Mai, T.; Mowers, M.; Uriarte, C.; Blair, N.; Heimiller, D.; Martinez, A. (2011). Regional Energy Deployment System (ReEDS). NREL/TP-6A20. Golden, CO: National Renewable Energy Laboratory.

Stillwell, A.S.; Webber, M.E. (2014). "Geographic, Technologic, And Economic Analysis of Using Reclaimed Water for Thermoelectric Power Plant Cooling." Environ. Sci. Technol. 48, 4588-4595. doi:10.1021/es405820j. 
Tidwell, V.C.; Malczynski, L.A.; Kobos, P.H.; Klise, G.T.; Shuster, E. (2013a). "Potential Impacts of Electric Power Production Utilizing Natural Gas, Renewables and Carbon Capture and Sequestration on U.S. Freshwater Resources." Environ. Sci. Technol. 47, 8940-8947. doi:10.1021/es3052284.

Tidwell, V.C.; Zemlick, K.; Klise, G.T. (2013b). Nationwide Water Availability Data for Energy-Water Modeling. SAND2013-9968. Albuquerque, NM: Sandia National Laboratories.

Union of Concerned Scientists. (2012). UCS EW3 Energy-Water Database. V.1.3. Cambridge, MA: Union of Concerned Scientists.

Van Vliet, M.T.H.; Yearsley, J.R.; Ludwig, F.; Vogele, S.; Lettenmaier, D.P.; Kabat, P. (2012). "Vulnerability of US and European electricity supply to climate change." Nat. Clim Change advance online publication. doi:10.1038/nclimate1546.

Ventyx. (2013). Ventyx Energy Velocity Suite.

Watson, I.; Morin, O.; Henthorne, L. (2003). Desalting Handbook for Planners, Third Edition Desalination Research and Development Program Report No. 72. U.S. Bureau of Reclamation.

Woldeyesus, T.; Macknick, J.; Colman, J. (forthcoming). A review of cost and performance characteristics of cooling system options at thermal electric power plants (NREL Technical Report). Golden, CO: National Renewable Energy Laboratory.

Woldeyesus, T.; Macknick, J.; Colman, J.; Stright, D.; Vorum, M. (forthcoming). Quantitative model to determine water withdrawal and consumption factors of thermal power plants utilizing multiple climate variables. (NREL Technical Report). Golden, CO: National Renewable Energy Laboratory. 